\title{
19. Documentary as Contemporary Art - A Dialogue
}

\author{
Wang Bing, Dominique Chateau and José Moure
}

\begin{abstract}
Wang Bing can be considered one of the greatest representatives of contemporary Chinese cinema. A meeting between him, Dominique Chateau and José Moure at a Master Class, as part of a series of Interface meetings at the Panthéon-Sorbonne University, Paris I in 2019, led to the idea of this present dialogue. Here, Wang (whose films are off the beaten track in many ways) clarifies his connection to various issues raised by post-cinema, in particular, the consequences of technological changes with regard to film creation and distribution and evolution in the aesthetic conception of cinema.
\end{abstract}

Keywords: China, documentary, art

Dominique Chateau/José Moure: The cinema you practice is in line with technological progress. Your way of filming people for long periods of time in the hope of a fruitful meeting, was difficult to envisage during the film-on-film era. What part and role do you assign to equipment in your documentary approach, and especially to lightweight digital cameras?

Wang Bing: ${ }^{1}$ It is true that small, lightweight video and digital cameras allow for a more direct link and above all greater freedom, in the sense that it makes it possible to integrate the environment of ordinary people and their daily lives into the shot. The light weight makes it possible to approach the characters as closely as possible, which gives you greater freedom, something you realize as you get closer to the subject, to the people you are

Chateau, D., and J. Moure. Post-cinema: Cinema in the Post-art Era. Amsterdam: Amsterdam University Press, 2020 DOI 10.5117/9789463727235_CH19 


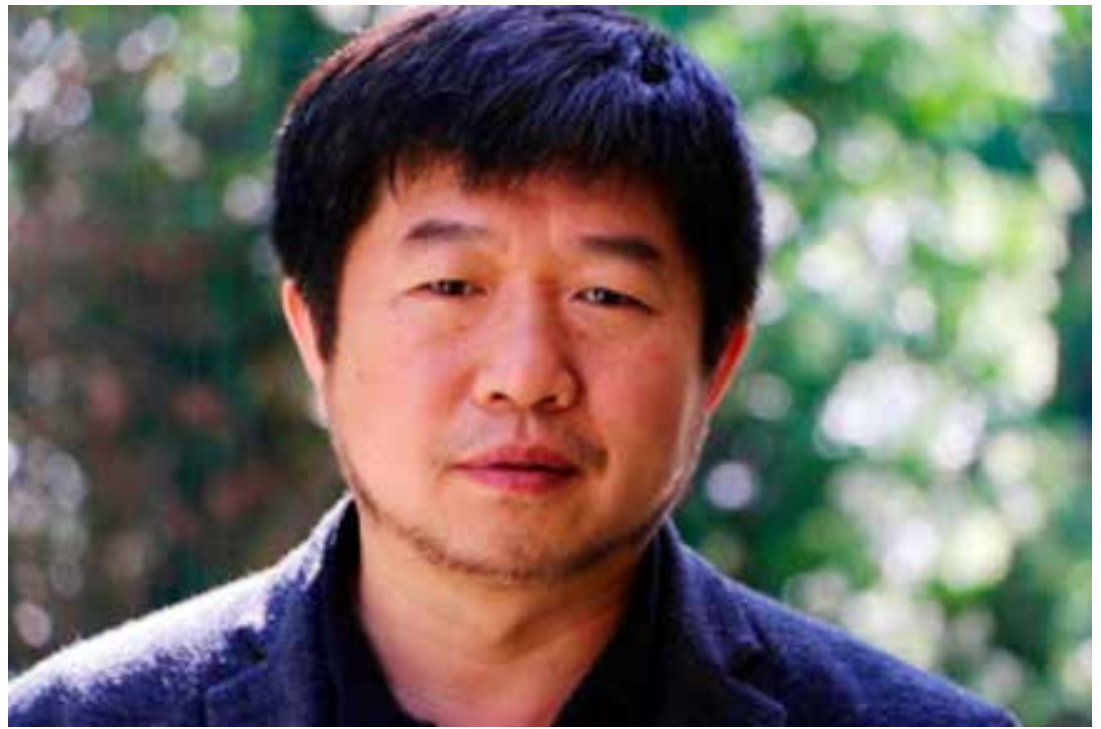

Wang Bing, 2019. Photo credit: Wang Bing

filming. It is thus another type of cinema, where characters can be filmed in close proximity, accompanied in their daily existence and in their lives until all barriers are overcome. This at once gives you a type of freedom, which you only appreciate as you get closer and closer to the subjects. It's a different cinematographic sensibility, a greater proximity to the truth, both in terms of people's inner motivations and their actions. With this equipment the observation is such that I myself feel as close as possible to that which I observe of people. On this basis, thanks to this equipment, I feel that I can achieve exactly what I want to in cinema. I thus feel attracted to the characters; I find a cinematographic possibility in them, which has the advantage of not being a copy of what already exists in cinema. Every time I embark on a new documentary, it is because I am attracted to the subject of my film.

DC/JM: The description of your approach to documentaries seems to indicate that you conceive of them in a particular way. Moreover, confining yourself to a genre seems contrary to your conception. You belong to a moment in the history of cinema and the media when the "classical" nomenclature is being challenged, in favor of an approach that is freer. Can you clarify your position as far as documentaries are concerned? How did you choose this film genre? How does it contribute to your conception of cinema? 
WB: Firstly, I must say that when I started making documentaries, I had not done any research nor special studies in relation to this genre; I had seen very few documentaries but, conversely, I had seen a lot of fiction. When you leave the institution where you studied, you are faced with the difficulty of looking for job opportunities. With the arrival of the Panasonic ${ }_{3} \mathrm{CDD}$ camera, I thought maybe it was a good idea to make documentaries, that it was a more plausible project. That's when I found myself in the world of WEST OF THE TRACKS (2003), the world of factories. I approached the shooting and my work as a documentary filmmaker under these conditions, with the experience that I had - the films I had seen during my studies, what I had read about cinema - and it was on that basis that I formulated my ideas on how to approach making films.

From the moment you take a camera to interfere with the universe of the characters you have decided to film, with their lives, there is an attraction that puts you on track of how the film will be made. It was in this rather risky way, which was quite limited as far as filming conditions were concerned, that gradually I was able to develop my film style, thanks to a light and very inexpensive camera which nonetheless opened up very wide horizons for me.

DC/JM: You made a fictional film, The DiTCH, whose subject is very close to that of your documentaries. Is there no boundary between documentary and fiction for you?

WB: I approach documentaries by being as close as possible to the characters. We know how objective cinema is, whether it is documentary or fiction. But as for the documentary, from the moment I speak in terms of cinematographic sequences, I consider that a certain sequence and that which brings it to life is true. Film is like putting truth sequences end to end; once they have been placed end to end, they will tell a story. On the other hand, for fiction, each image in the film is fiction, which does not mean that once these images have been reorganized, the result will not also be true in the end, but it will be a subjective truth. The purpose of organizing these images is to enable the viewer to exercise his or her subjectivity during his or her reading of them.

DC/JM: In the quest for subjects and during filming, does waiting play a role, waiting for something to happen, for an encounter to take place, for that encounter to seem worthy of being filmed? For example, can MAN WITH No NAME not be considered as a film about waiting in the way André Bazin defined Flaherty's NANOOK OF THE NORTH (1922)? More generally, 
these opportunities for encounters, these simple, daily events that you film, do they happen by chance or are they prepared or even provoked in one way or another?

WB: Film quickly becomes a part of your life from the moment you start in this business. When we start to think "cinema," to think about the different problems of cinema, everything relating to filmed characters and cinematographic form is very exciting and puts us in a certain state which is the desire to make films. When I met the man with no name in 2000 , when this character suddenly appeared in front of me, at that moment, standing before him, I immediately wondered how to make a film about him. It was obvious to me then: from the moment I took the camera to start filming him, everything that came into the frame had an incredible attraction. If your eyes are not fixed like that by what you encounter, you will not decide to film. I think that this is anything but a waiting position. If I were to take a waiting position, not only would I not have the patience, but I would have no intention of creating. I think that when one waits, it means that the attraction, which links image to character, is absent. It would make me nervous to be in this kind of situation; in that case, I would stop everything and stop filming. As soon as the camera starts rolling and we have a frame with a character who develops, whom we observe in his daily life, all the details, everything that is happening, every movement, every act is something which attracts me, which becomes my motivation, until the action ends: at that moment I stop the camera. I wasn't expecting the encounter with the man with no name at all, but after he had appeared before me and I had decided to film him, all these gestures, all these actions, everything that I had perceived and observed about him attracted me; there was no doubt about it then, I had to film him, if there had been any doubt, I wouldn't have filmed him.

DC/JM: You say that "to film is to travel." Gilles Deleuze spoke of "a film stroll" and, in a course on cinema, he said about people appearing in this kind of film: "what happens to them does not belong to them" (1982, n.p.; our translation). Is this a way to define the characters you film? What is your concern when you enter the dead zones that you film, where we meet the "dead souls"?

WB: If there is one thing that is certain, it is that to film I have to go to very different places. I am always traveling. But there are other meanings to this journey. Firstly, we suddenly find ourselves involved in the lives of others. 
Then, on an inner level, it is also a sensitive, sentimental journey. In any case, I am never in a creative situation against my will. I meet someone and I want to film this person. I need to be immersed in the place before initiating the act of filming. For example, for WEST OF THE TRACKS, I arrived on location in 1992, but I only started filming in 1999. In most cases, when I was filming, I was already familiar with the location and the people, and the time I spent there gave me more freedom of choice. In this case, I am in a state of optimal concentration. It's as though nothing bothers me, nothing interferes with my act of filming. To film people and children in their homes, on board the trains that circulate inside the factories, the time I spent living with them makes it easier to make the film and gives me greater freedom as a filmmaker.

As for the subject of DEAD Souls, it was initially a subject I did not know well. While the shooting of WEST OF THE TRACKS was completed in 18 months, the shooting of DEAD Souls lasted three years, from 2005 to 2008. Another feature of this film: it was while shooting that I was gradually integrated into the world of these people, that I gradually conceived of the subject I had to deal with. In fact, I was still shooting for this film until 2017.

As regards the choice of film subjects, as regards the time and country in which I live, as regards what is happening in my region, I absolutely need to address subjects that make me want to move on to directing. I am not a filmmaker who can respond to commissions.

DC/JM: In the interaction with the characters you film, for example in your relationship with the woman you interview in FENGMING, A CHINESE MEMOIR, there is a certain distance and minimum interaction. It would seem that, for you, respect for the other and erasure of the filmmaker go hand in hand. Can this attitude be considered a way of conceiving the filming device? At the same time, there is the question of your own body, in the sense that filming requires physical adaptation. For example, when you enter the "hole" where the "man with no name" lives. Do you think that cinema passes through the body as much as through speech?

WB: From the moment you decide to make a film, what matters is the location of the film, where it takes place; what matters is to control the film situation and not the feelings that bind you to the character. Of course, during the filming process there are sometimes sudden breaks, sudden changes that require getting closer to the subject, changing direction, changing the way we film, according to a transformation which affects feelings. Sometimes, on the contrary, we allow what we are documenting to happen 
and we prevent ourselves from abandoning ourselves to feelings. When we focus on the frame, sometimes, in the midst of everything happening inside it, actions, characters, gestures, something forces itself on us, so that we have to get as close as possible to the subject, to feel in the most intense way possible what is happening; we are then confronted with the question of the right distance, the perception of the right distance which will make people feel what we are feeling ourselves. For example, in the case of MAN WITH No NAME, just because the cave he is living in is dirty does not mean that the camera has to stay outside; if we have to enter this universe, we enter it. I think that everything which interests me and which fits into the frame of my camera, everything that transpires from the character's living environment, because we followed him to enter his universe, also produces the interest that the viewer will experience and that will make him or her decide to continue watching the film.

DC/JM: Is there an aesthetic aim in your films? By aesthetic aim, we can firstly understand the choices of genre, form, subject that constitute your personal aesthetics (your personal conception of the aesthetic value of the film). How do you define your personal aesthetics? By aesthetics, we can also mean aestheticization (in Walter Benjamin's sense): to aestheticize the world is to beautify it, to eventually make it acceptable to those who are its victims; Walter Benjamin ([1935] 2003) said that fascism aestheticizes war, the masses, etc. The characteristics of your relationship with the filmed subjects suggest that you refuse this embellishment, but that you also refuse any affirmation of ideology or political position.

WB: When, after my studies, I started directing, my personal background differed from that of Western directors, among others. Whether in terms of cinematographic style, the conception and aesthetics of cinema and, beyond cinema, the entire artistic world, what characterizes China is strongly determined by an ideology that corresponds to a system and an ideological history that leads to a certain aesthetic, according to a certain norm in force. I started working at the turning point of the millennium, in 1999-2000, at a time when, for many artists in China, the way of working changed considerably. I remember that at the time, in a country guided by an ideological and aesthetic norm, I was driven by the absolute need to break away from that norm, by the essential objective of breaking with those habits.

I think that people's relationship to cinema, their understanding and knowledge of it, is determined by society; what is determined by society 
influences us personally, even if subconsciously. What matters to me is to forget about it as much as possible. It is not only about the fact that we cannot tell a certain story, approach a certain subject, say things in a certain way, it is much broader than that in the sense that it is a form that is imposed on us, an aesthetic that is imposed on us. My first reaction is to forget all this, so that it does not appear in my films as a constraint that would pollute them. This means that we must build our own perception of things through a permanent reflection on what we want and what we do not want, in order to find ourselves in front of the blank page of a blank space of creation. The question is not simply to film something real or not, that is more true or not, but to face a culture in its entirety. It is not like asserting a political position, even if my political position is very clear, but it is about cleaning up anything that could disrupt the film itself in terms of the art form as a whole. It also means that we must return to the fundamental questions: what is cinema, how is it defined and what is our relationship to it?

DC/JM: In 2009, the Chantal Crousel gallery dedicated a solo exhibition to you. FeNGMING and MAN WITH No NAME were screened on this occasion. In 2018, again, there was a second exhibition in the same gallery with the projection of the long version of MrS FANG and BEAUTY LIVES IN FREEDOM (while TraCEs [2014] was "continuously broadcast in the exhibition space"2). You express your preference for this method of distribution, which associates you with contemporary art. What does it mean to you to transfer cinema into the exhibition space and to match it with contemporary art? What is the difference between the presentation of your films in museums and in a cinema?

WB: You could say that a cinematographic work in cinemas is characterized by the fact that there is a story, a narrative, but it is more complicated than that insofar as each director has his own way of conceiving the story and the narrative. If a film seen in a cinema had no narrative line, it would be missing something, whereas in installations and museums the situation is different. From the moment the animated image was on film, with the Lumière Brothers or Edison, the envisaged goal was to project it in a cinema in front of an audience, while the appearance of digital technology produced new material reinvested by animated images, which does not necessarily belong to the cinema legacy. Audio-visual images are different from cinema;

2 See https://www.crousel.com/home/exhibition/1108/Wang-Bing (Galerie Chantal Crousel 2018; our translation). 
projected in the exhibition space, they are part of an expansion of the image in relation to the material and space of cinema. Just because we are talking about moving images does not necessarily mean that we are talking about cinema: we can look at moving images in exhibition spaces or on our smartphones as well as in a cinema. It is as though the image were an independent material and then it became cinema or something else. The fact that birth determined a link between the moving image and cinema does not mean that they are linked forever. Cinema has a real tradition in terms of storytelling, narrative, but various habits that we later adopted in the audio-visual sector have been disconnected from this tradition of cinema. This is the new experiment that we are making with audio-visual material that can be used in the gallery and museum exhibition to target another form of expression. With the advent of digital technology and new materials, it is a bit like a virus that circulates at high speed and invades the whole space. It is as if the artists who used images for installations in exhibition spaces carried with them an aesthetic experience and even an experience of the narrative that was different from that which could be drawn from film practice. I can relate to that; these new ways of producing and distributing images arouse my curiosity, as well as another way of looking at documentary and a different experience in which I want to participate. On a daily basis, in my reflection, I have moved from a reflection related to cinema to a reflection more related to the conditions of exhibition in contemporary art.

DC/JM: In that case, your aesthetics are characterized by an emancipation from any preconceived idea of what a film should be. In addition, this freedom is reflected notably in the length of the films. For example, DEAD Souls, presented out of competition at the 2018 Cannes Film Festival, is a film of more than 8 hours and 15 minutes. What makes this film duration possible?

WB: We were saying earlier to what extent digital technology has brought great freedom to cinema, to what extent it is a great revolution for cinema, but now there is also the multiplication of broadcasting methods. So I have works that are presented in galleries and museums, and we can find ourselves in this kind of space with a work broadcast from 10 a.m. to 5 p.m., over an eight-hour period, just like we can do a 30 -minute work and play it over an 8-hour period. This urges me to use this distinctive feature of time in its length, particularly because in the space of eight hours we can have a work that will not be repeated; it allows people who enter the space and 
find themselves facing the screen to decide for themselves if they will stay for a short time, see only one passage or, on the contrary, stay for very long.

If, for me, it is a different situation from cinema, it is to the extent that the animated image is presented in the exhibition space; on the other hand, when I shot DEAD SouLS, which was 8 hours and 15 minutes long, I wanted to make a work of cinema and not a work for galleries or museums. The reason for the 8 hours and 15 minutes lies in the subject, in a very rich content that would have made it impossible to make a short film. I know that, in relation to such a long work, there are many people who, to the extent that today we do not have to see films in cinemas, would choose to watch it at home. For me, whether it is a story or an event, from the moment we decide to tell it, it must be done in the most complete way possible, the narrative must be as complete as possible.

As regards DEAD SouLs, for the moment I have only directed one part of it. There are still two parts that have not yet been edited. It is a project in three parts: the first part thus consists of 8 hours and 15 minutes; the second part will be a little longer. Anyway, the project will be one in which each of the sections is about eight or nine hours long. It may seem like a very long time, but I think that a person who has decided to watch a certain subject is free to do so at his own pace, dividing the film as he wishes.

DC/JM: At the Sorbonne, you said: "My works in themselves, whether exhibited in a museum or gallery, are without interest, but the people [who have been filmed] have a place in a museum or gallery." You display a precise position, which regulates both your relationship to observation ("art is observation") and to the filmed subjects: they are the people that society neglects, that History has crushed and emptied, so that their presence in the film and their exhibition in the gallery constitute a solemn act. May we say about you what Jonas Mekas (2016) said about independent cinema: ethics dominates aesthetics?

WB: I am extremely respectful of the work done in museums, of the collection of the works done by them, and I wonder what I can do for them with the utmost seriousness. I absolutely do not want to rush things and I am thinking about the most serious way to respond to requests. Generally, I am keen to put the focus on those characters who are part of my contemporary works of art, because they endure a lot of suffering as individuals, both in terms of history and of their personal characteristics, in terms of what China represents, but also in terms of their talents. For example, given that the museum space is an extremely serious, demanding place, I believe that 
the characters of Fengming (in Fengming, a Chinese Memoir) or Gao Ertai, the man I filmed in BEAUTy LIVES IN FREEDOM (2018), and others to come, all have their place here, especially when you see how little respect anyone in China has for them. These are human beings who are never chosen in China to be in the forefront. When I realized that galleries and museums were interested in my work, I thought it was an opportunity for those individuals to enter these spaces, so that they too could have their place as individuals among the collections of artworks.

\section{Translated by Naòmi Morgan}

\section{References and Further Reading}

Benjamin, Walter. (1935) 2003. "The Work of Art in the Age of Its Technological Reproducibility." In Walter Benjamin: Selected Writings, 1938-1940. Vol. 4, edited by Howard Eiland and Michael W. Jennings., translated by Harry Zohn and Edmund Jephcott, 251-283. Cambridge, MA: Belknap Press.

Deleuze, Gilles. 1982. "La voix de Gilles Deleuze en ligne.” Université Paris 8. May 4, 2005. http://www2.univ-paris8.fr/deleuze/article.php3?id_article=155.

Fiant, Antony. 2019. Wang Bing, un geste documentaire de notre temps. Laval: Warm.

Galerie Chantal Crousel. 2018. "Wang Bing: 1er - 22 décembre 2018." https://www. crousel.com/home/exhibition/1108/Wang-Bing.

Mekas, Jonas. 2016. Movie Journal: The Rise of the New American Cinema, 1959-1971. New York: Columbia University Press.

Persico, Daniela, ed. 2010. Wang Bing, Il cinema nella Cina che cambia. Milan: Agenzia X.

\section{About the Authors}

Wang Bing, born in 1967 in Xi'an in the Shaanxi Province, can be considered one of the greatest representatives of contemporary Chinese cinema (along with Jia Zhangke). He studied photography at Luxun Arts University in Shenyang and film at Beijing Film Academy. He has directed both fiction and documentary films including: WEST OF THE TRACKS (2003), FENGMING, a Chinese Memoir (2007), Coal Money (2008), Man with No Name (2009), The Ditch (2010), Three Sisters (2012), Till Madness Do Us Part (2013), TÁAng (2016), Mrs. FANG (2017), BeAUty Lives in Freedom (2018) and DEAD Souls (2018). Books on his filmic work include the Italian collection of texts, 
Wang Bing, Il cinema nella Cina che cambia (2010), and the recent book by Antony Fiant, Wang Bing, un geste documentaire de notre temps (2019).

Dominique Chateau is Emeritus Professor of Aesthetics and Cinema at the Sorbonne School of the Arts at Panthéon-Sorbonne University, Paris I. His books include: Cinéma et philosophie (2003), Philosophies du cinéma (2010), Subjectivity (ed. 2011), Linvention du concept de montage. Lev Kouléchov, théoricien du cinéma (2013), La direction de spectateur (ed. 2015), Après Charlie: Le déni de la représentation (2016), Screens (ed. 2016), Contribution à l'histoire du concept de montage (2019), Esthétique de la recréation (ed. 2019), and Une esthétique japonaise (2019).

José Moure is Professor of Cinema Studies in the Sorbonne School of the Arts at Panthéon-Sorbonne University, Paris I. He is director of the Research Institute ACTE. He teaches film aesthetics and film analysis. He is the author of Vers une esthétique du vide au cinéma (1997), Michelangelo Antonioni, cinéaste de l'évidement (2001), Le cinéma: Naissance d'un art (with Daniel Banda 2008), Le cinéma: L'art d'une civilisation (with Daniel Banda 2011), Avant le cinéma. L'oil et l'image (with Daniel Banda 2012), Le plaisir du cinéma. Analyses et critiques des films (2012), Charlot: Histoire d'un mythe (with Daniel Banda 2013), Screens (with Dominique Chateau 2016), and Histoire vagabonde du cinéma (with Vincent Amiel 2020) 
